\title{
Economic Geography in the Internet Age
}

\author{
Francesco Grillo ${ }^{*}$, William H. Dutton ${ }^{* *}$, Cristóbal Cobo ${ }^{* * *}$
}

\begin{abstract}
Internet is shaping what jobs go where. It provides an account of how concentration is changing in different industries and different sectors. It analyses these trends and proposes an approach to further research which may move the theory of agglomeration so that full consideration is given to the forces that the Internet has enabled.
\end{abstract}

Keywords: Economic Geography; Internet; Endogenous Growth Theory; European Union; Clusters; Global Markets

\section{Introduction}

As the Internet has diffused to wider proportions of nations across Europe, how has the distribution of the workforce been changing across different industries that are more or less anchored in information-centric work? Could Information and Communication Technologies (ICTs) be playing an important role in the redistribution of jobs? This research question is one critical component of a much wider debate over how technologies are reshaping the geographic distribution firms and industries across the information economy.

In 1890, Alfred Marshall argued that “... every cheapening of the means of communication alters the action of forces that tend to localise industries". This perspective on the role of communication technology in the distribution of work has been empirically studied over the years, with various levels of support, but remains an important assumption behind the economic implications of change in digital communication technologies like the Internet (Goddard and Gillespie 1996), and speculation on the 'death of distance' (Cairncross 1997). Arguably, the Internet has reduced the unit costs of receiving, processing, and transmitting information, perhaps more so than any technology since the invention of the printing machine, and this could enhance or detract from the importance of location, depending on the

\footnotetext{
* Francesco Grillo, Professional Affiliate of Innovation Management, Scuola Superiore Sant'Anna di Pisa (francesco.grillo@sssup.it)

** William H. Dutton, Quello Professor of Media and Information, Quello Center, Michigan State University (wdutton@msu.edu)

*** Cristóbal Cobo, Director Study Center CEIBAL Foundation in Uruguay, Associate Researcher, Oxford Internet Institute, University of Oxford (ccobo@plan.ceibal.edu.uy)
}

Grillo Francesco, Dutton William H., Cobo Cristóbal (2015) Change and Stability in the Economic Geography of Information: The Distribution of Jobs over Time and Across Industries in the Internet Age, Symphonya. Emerging Issues in Management (symphonya.unimib.it), n. 1, pp. 44 - 63. 
nature of work. This has led to speculation about variations across industries (Cairncross 1997). Most generally, if Marshal's expectations are correct, the Internet should be a major factor shaping the redistribution of economic activities, enabling geography to be less deterministic of the location of industrial firms.

With the rapid diffusion of ICTs, such as the Internet, since the early nineties, two extreme visions have developed around their impact on the geography of firms primarily focused on the distribution of jobs, along with many more intermediate points of view. At one extreme are the proponents of the death of distance (e.g., Cairncross 1997), who expect ICTs to make distance irrelevant in a economy which tends to become 'weightless' (Quah 2000): in this context even the notion of centre and periphery may vanish and concentration - together with inequalities amongst regions - should gradually disappear and firms become more widely distributed when no longer required to co-locate to obtain critical access to information and communication.

At the other extreme are the proponents of the rise of geography, who argue that electronic access to information will lead firms to locate where they can enhance face-to-face communication with those in their networks (Goddard and Richardson 1996). Consider the success of cases like Silicon Valley considered for decades as the global engine of the Internet revolution based largely on the informal communication and networking occurring within and across firms. From this perspective, the Internet is creating a 'new economy' where geographical proximity is indeed more and not less important (Kolko 2000; Koski et al. 2000) and where clusters of interrelated economic activity become a key to economic growth (Porter 1990).We have taken neither viewpoint for granted, since there are empirical arguments for challenging both extremes on how the Internet is or is not changing the geography of economic systems. On the one hand, there is ample evidence that distance is not dead, and that geography still matters (Goddard, Richardon 1996). However, there is also much evidence that the Internet is profoundly changing the way firms and workers do what they do (Brondoni 2008). More specifically, we believe there is good reason to continue to examine empirical evidence that can challenge the traditional accounts of the economic geography, and how technologies might reconfigure economic growth and, shape differences in growth amongst and across different countries and regions, as economic activities gradually adapt their spatial distribution to the affordances of new media. Such factors as transportation costs, proximity to customers and suppliers, the sharing of more distributed value chains, and access to skilled workforces may be not as important as they used to be; but information and network externalities, and knowledge spill-overs may matter more and may even require a radical rethinking of the categories of any analysis of the concentration of economic activities within firms, industries and within nations (Rifkin 2014). However these new economically relevant forces are still far from being identified, much less operationalized.

This paper begins with a review of opposing theories of the new economic geography and how they are tied to the diffusion of digital technologies. This is followed by the presentation of evidence of how concentration has changed over time across different countries and industries, and how this is associated with different uses of the Internet. The final section discusses the results and identifies the need for further researches. 


\section{Why the Location of Economic Activities Matters and How Does it Change}

Paul Krugman and Tony Venables (1995) have argued that the distribution of economic activities between the centre and periphery of an economic system has been driven by the increase in international trade which has been triggered, in turn, by a reduction of barriers and costs to exchange across regions and countries. When trade costs decrease, agglomeration, or the concentration of industrial activity in certain places, increases for two reasons (Bellini 2012; Puga 1999 and 2002; Forslid et al. 2002).

First, as competition among firms is less restrained by trade costs, the initial outcome should be the elimination of less efficient producers and a greater concentration within industries (and consequently among suppliers and buyers). This means that more profitable firms are likely to concentrate in regions that can provide better access - lower costs - of access to suppliers and workers. Consequently, these regions tend to grow their industrial base, and, eventually, GDP per capita. Secondly, firms whose factories were located in different regions have a smaller incentive to be closer to final customers (as in a model where two regions are separated by high 'trade' costs) and the incentive for them is to concentrate their assets in the same (most likely home) location.

As a result, the regions with better endowments (e.g., education, infrastructure, legal systems, security, natural resources, etc.) capture greater shares of other regions' markets, leading them to increase their share of the total production base ${ }^{1}$. In such a context, agglomeration is believed to increase the return on investments. Any intervention that is designed to reduce the spontaneous agglomeration of economic activities and the resulting inequalities, is seen by some of the economic geographers (Midelfart-Knarvik, Overman 2002; Boldrin, Canova 2001) as suboptimal, because it would reduce total economic output. In fact, in Krugman and Venables' model, if spontaneous market forces are left alone, they will drive the system to a new equilibrium where initial gaps amongst regions will be reduced. Cheaper labour costs in the periphery as well as a surge of costs due to congestion in the centre will reverse the agglomeration pattern. This does not mean that regions will eventually become what they used to be before the initial relocation: more likely, they will tend to specialize in some specialised areas of production so that the economic system as a whole may maximize the advantages for firms being close to their partners and competitors and minimize the costs of congestion.

The explicit assumptions of all above reflections is that concentration of jobs matters and that, in fact, economic activities become more or less concentrated because this is exactly what will drive - all other things being constant - increasing returns (as in Krugman 1990) or competitive advantages (Porter 1996).

However, the "reversed U shaped pattern of agglomeration/ divergence followed by specialization/ convergence" does not necessarily operate where labour mobility and wage differentials are limited, such as by interventions or national boundaries. This is the case of Europe where the rather simplistic notion of 'concentration' is instead frequently replaced by the more sophisticated notion of clusters. 


\section{The Merits and The Limits of Clusters as Key to Innovation and a Tool for Regional Development}

Michael Porter (1990) has attempted one of the most widely referenced systematization of the reasons why clusters may be crucial to achieve higher levels of productivity and, thus, an acceleration of economic growth. The key variables are not - as for the new economic geography - the physical proximity to clients or suppliers and, therefore, a shock in terms of a reduction in the costs of transportation or of trading. What really matters from Porter's analysis is the spillover of soft production factors, such as imitation and the search for leadership amongst competitors, the knowledge sharing and the trust between suppliers, and the feedback that a demanding client basis may provide. In a later treatment of version of clusters, it becomes the key to something even more crucial for generic productivity: innovation. Ernest Wilson (2004) goes beyond the economic actors and sees regions as capable of innovation only when the links amongst firms, research, civil society and government are sufficiently dense for problem solving to involve all parties whose collaboration is necessary for innovation to unfold.

Linked to the idea of a cluster, is the concept of a local innovation system which has been prominent in academia and policy-making circles for decades. The basic idea underpinning the conceptualization of a local innovation system is that the tacit knowledge that is an essential component of innovation cannot be understood or even created "purely in terms of independent decision making at the level of a firm" (Dilling-Hansen 2000) or of a single inventor. Thus it can be viewed as an "interactive, collective, entrepreneurial learning process" (Lundvall 1992 which also applies to cities as clusters; Cappellin 2011) across different organisations and domains (public and private, research and business, see also Nanetti 2011, as far as cities are concerned). Moreover, the more adequate level to observe such a learning system is at a to subnational level ${ }^{2}$, indeed local, where the reduced spatial distance facilitates the complex interactions that innovation may require (Lundvall et al, 2007) and for the trust - which is also necessary for this form of strategic collaboration - to consolidate (Rizzi et al. 2012; Freel 2001) ${ }^{3}$.

Philip Cooke (2007), together with Asheim and Boschma (2011) qualify the idea of a local (or indeed regional) innovation system by introducing the idea of related variety. That is, the best clusters might lie somewhere between full diversification and strong specialization, where not one but more than one industry are represented although they are 'related' because they may add value to each other and operate in activities that have a link.

Another aspect of successful clusters revolves around the concept of knowledge bases. A distinction is put forward between analytic (typically new drug development and, more broadly, natural science where research's results tend to be codified and patented and where break through in product innovation are more frequent), synthetic (also called engineering research where innovation tend to proceed per marginal improvements and most of knowledge is incorporated in the individual employees' experience and skills) and symbolic (like in production of culture and art where changes happens through interactions with an even wider set of actors and the personal relationship, the 'know who' other is engaged in the creativity process is key) bases.

The implication of this thesis is that the more successful clusters may be the ones where different industries are present and yet the 'knowledge bases' are of a similar 
enough nature that the transmission of knowledge (for instance between group of architects, firms specializing in advertising and movie makers) is maximized.

Cooke and his colleagues maintain that in the environment institutions' main task should be to "construct regional advantage by building a policy platform" (Cooke et al. 2011). A policy platform is a communication platform whose aim is to: a) promote exchange of knowledge (and interactive, collective learning exercise as Lundvall 1992); b) identify (as Cooke 2007 clarifies) the actors that are capable to add value (and knowledge); and c) avoid this exercise becoming captured (as Barca 2009 reminds) by either too few (as in the case where a firm or a university plays a monopolistic game and exploits the public intervention in its favour) or too many (which would produce a dilution of the investments as in Grillo 2012). The concept of a 'policy platform' suggests a function where the Internet could play a crucial role as an enabling technology.

\section{The Impact of the Internet and the Paradox of the ICT Clusters}

At the extreme, the Internet has been seen as a force for changing the economic geography of industries by lowering transaction costs to an extent that reduces the problems of distance, what Frances Cairncross (1997) has called the death of distance. From this perspective, information technologies will change the company of the future (Cairncross 2002), where her reasoning appears to follow the classic argument of Richard Coase (1937) in which firms are said to exist in order to minimize the very transaction costs which the Internet can reduce. The impact of Internet is, therefore, potentially great, and ultimately challenges each of the phases of the casual chain which is supposed to require more geographical concentration in order to achieve higher levels of collaboration, enable this to be translated into more innovation and, ultimately, into superior economic performance.

Specifically, according to some authors (e.g. Quah 1997), the spread of ICT makes it less important for innovators to stick close together in order for relationships to develop. Moreover, collaboration does not automatically produce more innovation as the Internet itself has made the birth of many new start-ups possible, and increased the likelihood that some breakthroughs may take place in isolation (Hill, Rothaermel 2003). Also, innovation is becoming less closely linked to measurable economic outcomes. For instance, ICT based innovations are creating improvements in the quality of lives that do not necessarily translate into a measurable improvement of economic performance (as we mentioned below, amongst others Solow 1987 and Gordon 2000).

However, whereas the Internet makes geographical concentration less relevant, the very success of the ICT industry appears to be strongly associated to some of the strongest, more territorially bound clusters of the world, with the most famous being Silicon Valley (Vicente, Suire 2007; but see also Koski and others for treatment of the concentration of the ICT industry in Europe).

Whereas this paper is interested to the clustering of jobs across industrial sectors and is not focused only on ICT clusters, the resilience of agglomerations call for a different explanation of the forces driving firms to locate near to each other. Vicente (2003) argues that clusters can be explained as a convergence in locational choices resulting from exchanges of knowledge and models, which tend to be sequential and cumulative. Moreover, he distinguishes from what he calls 
informational externalities (and observational learning) from network externalities (and interactive learning): the two patterns are useful to even distinguish two different typologies of clusters. The informational externalities (found in some French ICT districts) are about reputation sharing which result from belonging to a certain community; the network externalities (which are typical of the Silicon Valley) are, instead, about innovating products, behaviours, and business models through sharing of tacit knowledge ${ }^{4}$.

That said, many of these expectations around externalities do not provide a clear approach to operationalization and, reflecting this issue, there has been little attempt at measurement of these forces.

\section{Empirical Analysis and Results}

To gather evidence on clustering, it is important to also deal with the closely related concept of 'concentration' is changing across different industries and countries, and whether differences in the magnitude of these changes can be attributed to the use of the Internet across sectors and societies. As an indicator of concentration, we took the geographical distribution of employees in different industries provided by EUROSTAT ${ }^{5}$, which enabled us to derive four different indicators of concentration. These include four concentration indices:

To gather evidence on clustering, it is important to also deal with the closely related concept of 'concentration' is changing across different industries and countries, and whether differences in the magnitude of these changes can be attributed to the use of the Internet across sectors and societies. As an indicator of concentration, we took the geographical distribution of employees in different industries provided by EUROSTAT ${ }^{6}$, which enabled us to derive four different indicators of concentration:

1. The standard deviation of the distribution of workers belonging to a certain industry amongst the regions ${ }^{7}$ of a certain country, compared with the standard deviation in the distribution of population;

2. The percentage of the total number of people working (employees) in a particular sector in the top five regions (or provinces of a country), compared to the percentage of general population that lives in these five most populated areas; and

3. The ratio between the share of employees working in the single province with the highest number of workers in a certain sector, compared with the share of the population living in the most populated province; and

4. Change in time of the first of these indicators (standard deviation of the percentages of workers of a certain industry working in each area).

We are using a proxy for measuring the concentration of economic activities, which is the distribution of the workforce. This does not, of course, coincide exactly with the distribution of firms, but it is an approximation of measurements that economic geographers have used, as we saw before, when calculating the effects of changes in trade costs on concentration (Krugman, Venables 1995).

We calculated these indicators for 12 different European countries (UK, Italy, France, Germany, Spain, Poland, Netherlands, Hungary, Portugal, Sweden Greece, 
Czech Republic). Together, they cover more than 90 percent of the EU economy, and include member states that capture variance between Northern versus Southern; countries which were most and least effected by the economic and sovereign debt crisis of 2007; and old and new EU member states.

For each of these countries we examined thirteen industrial sectors: five belonging to the broad manufacturing sector (textiles, chemicals, metal, machinery and vehicles which includes automobile manufacturing); six tied to the Information Communication area (Publishing, Computer programming, Information Services, Telecommunications, Video and Film industries, and Broadcasting); jobs in 'professional' activities (accountants, lawyers, general practitioners, consultants ..) and construction. This enables us to examine potential implications of the Internet across a diversified range of industries. Annex 1 includes the full dataset.

This comparative analysis revealed a number of related patterns, discussed in the following sections.

\subsection{Stability and Change in the Concentration of Jobs}

Since 2000, concentration levels have been relatively constant, neither dramatically increasing or decreasing. Out of the 156 cases considered (13 sectors times 12 countries), the number of the national industries where concentration is decreasing (76) are roughly equivalent to the numbers where it is growing (80);

However, this rough equivalence masks some patterns of change within sectors and across countries. Specifically, comparing sectors, concentration in ICT related industries has remained relatively stable, whereas concentration in manufacturing is increasing in 'automobile manufacturing' and 'machinery' while decreasing in 'chemical' and 'metal products'. With respect to services, the "computer programming and consulting" industry has become more concentrated, but largely due to a strong move towards agglomeration in eastern European countries (Annex $1)$.

With respect to all of these patterns, the changes are relatively small. Given that the changes are tracked over an 11 -year period, a variation of $11,5 \%$ is equivalent to an average annual change in concentration of only 1 per cent. 
Graph 1: Change in Time of Concentration by Sector (Standard Deviation of Workers amongst Areas), Per cent in 2011- 2000.

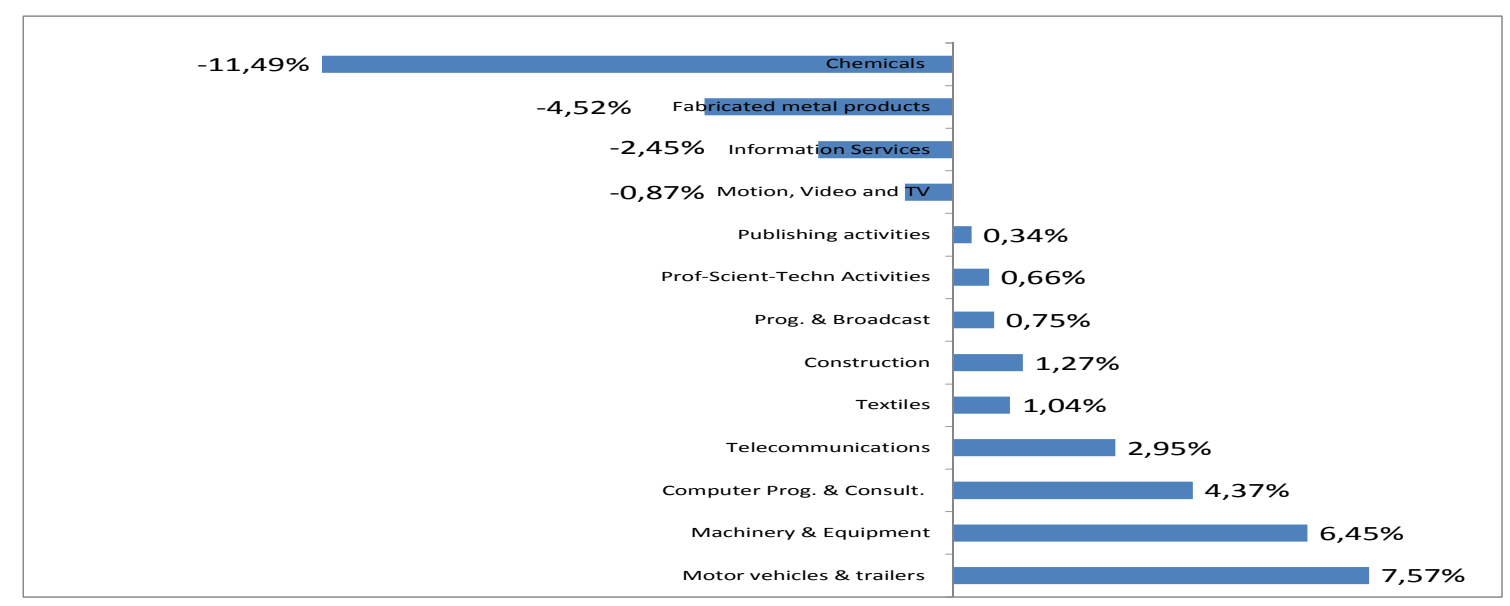

Source: Eurostat

More concretely, the comparison of countries shows that there were only three cases where the concentration changed by more than 10\%: activities in the Czech Republic and France became more physically clustered, while less clustered in Spain.

Graph 2: Evolution of Concentration by Countries (C-Standard Deviation of Workers amongst Areas), Per cent in 2011- 2000.

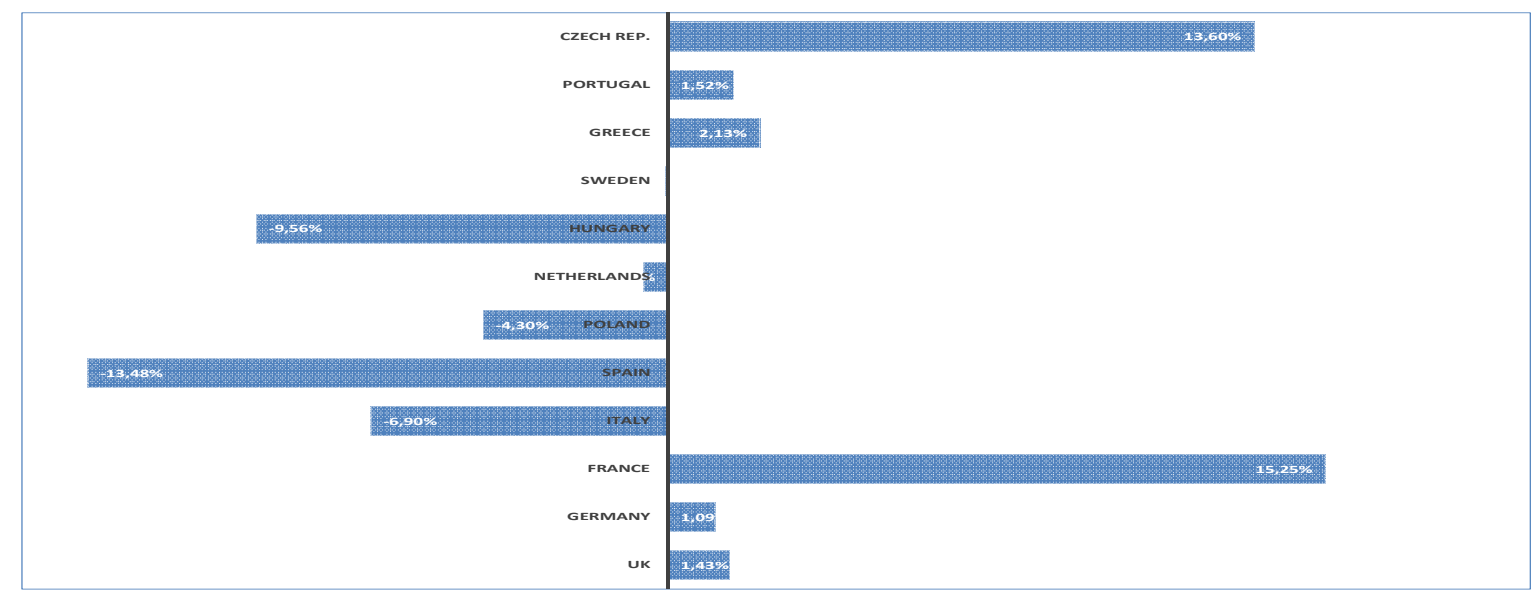

Source: Eurostat

It is, however, more interesting to look at the correlation amongst changes in concentration in different countries, and accessibility to Internet, as well as propensity to use it. 
Graph 3: Correlation between Change (2011 - 2000) in Concentration (Standard Deviation of Workers amongst Areas) and Digital Infrastructure, by Countries.

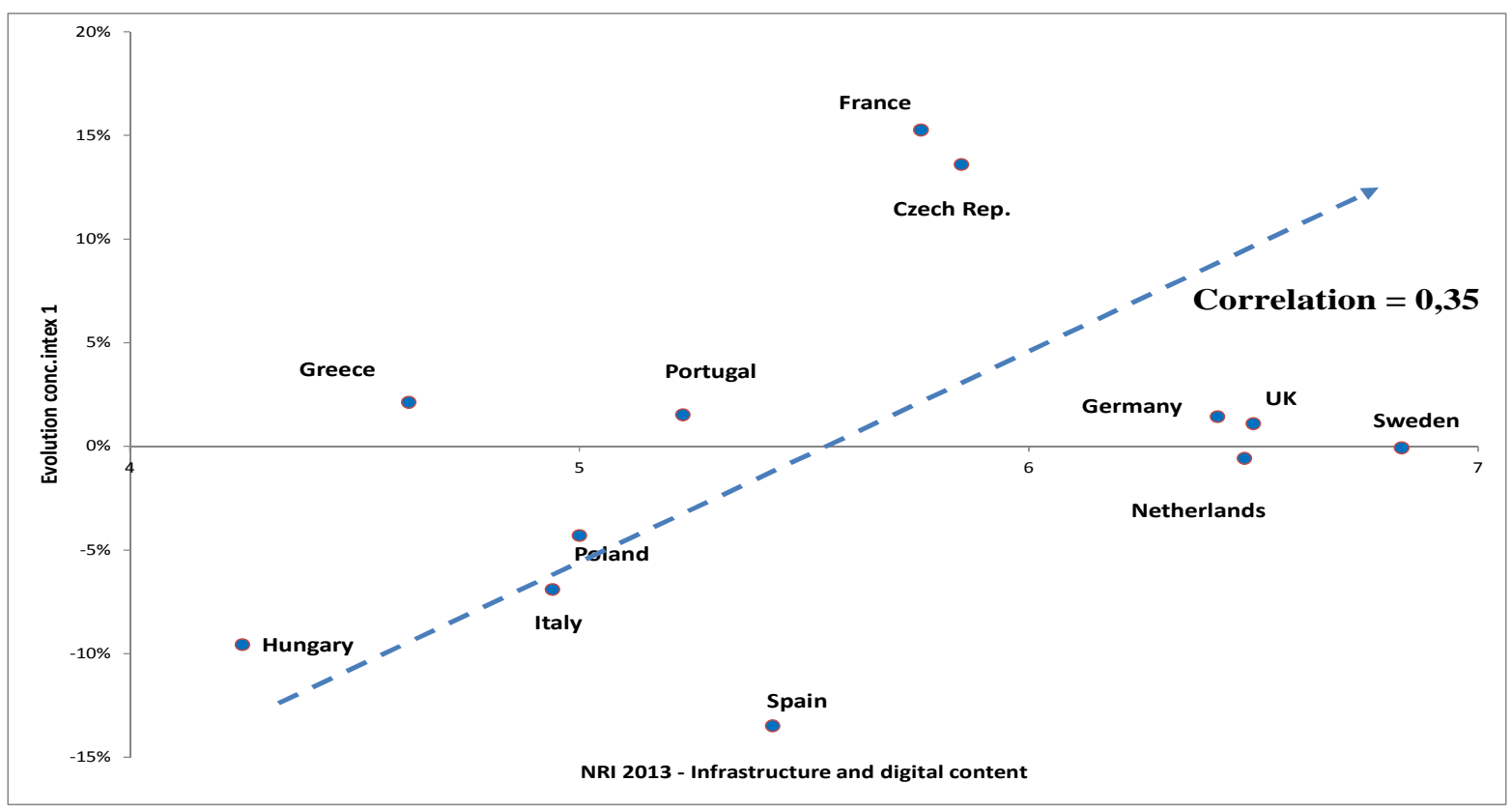

Source: Eurostat

However, overall, there is a correlation of clustering with the quality of the infrastructure: the better the infrastructure, the more countries tend to cluster their economic activities.

A similar result was found when looking not just to the supply of technologies but also to demand. For example, concentration is positively correlated $(0,29)$ with the use of ICTs by business of ICT. This relationship is similar even when substituting the ranking of the Knowledge Economy Index of the World Bank of ICTs business usage: correlation of changes in concentration and the diffusion of ICTs is weaker but still positive $(0,15)$.

Basically the more Internet-ready a country, the more economic activities tend to get agglomerated. Online networks tend to be correlated with face-to-face access, contrary to the expectations of the 'death of distance' thesis.

The absolute levels of agglomeration of economic activities. If we move ourselves from trends to absolute levels, data appear to convey even stronger relationships. Comparatively, concentration is higher in the Information and Communication sector, as well as in Professional Services, than in the Industrial or Construction sectors; 
Graph 4: Concentration (Ratio between Standard Deviation of Workers amongst Areas and Standard Deviation of Population), By Sector, Per cent, 2011.

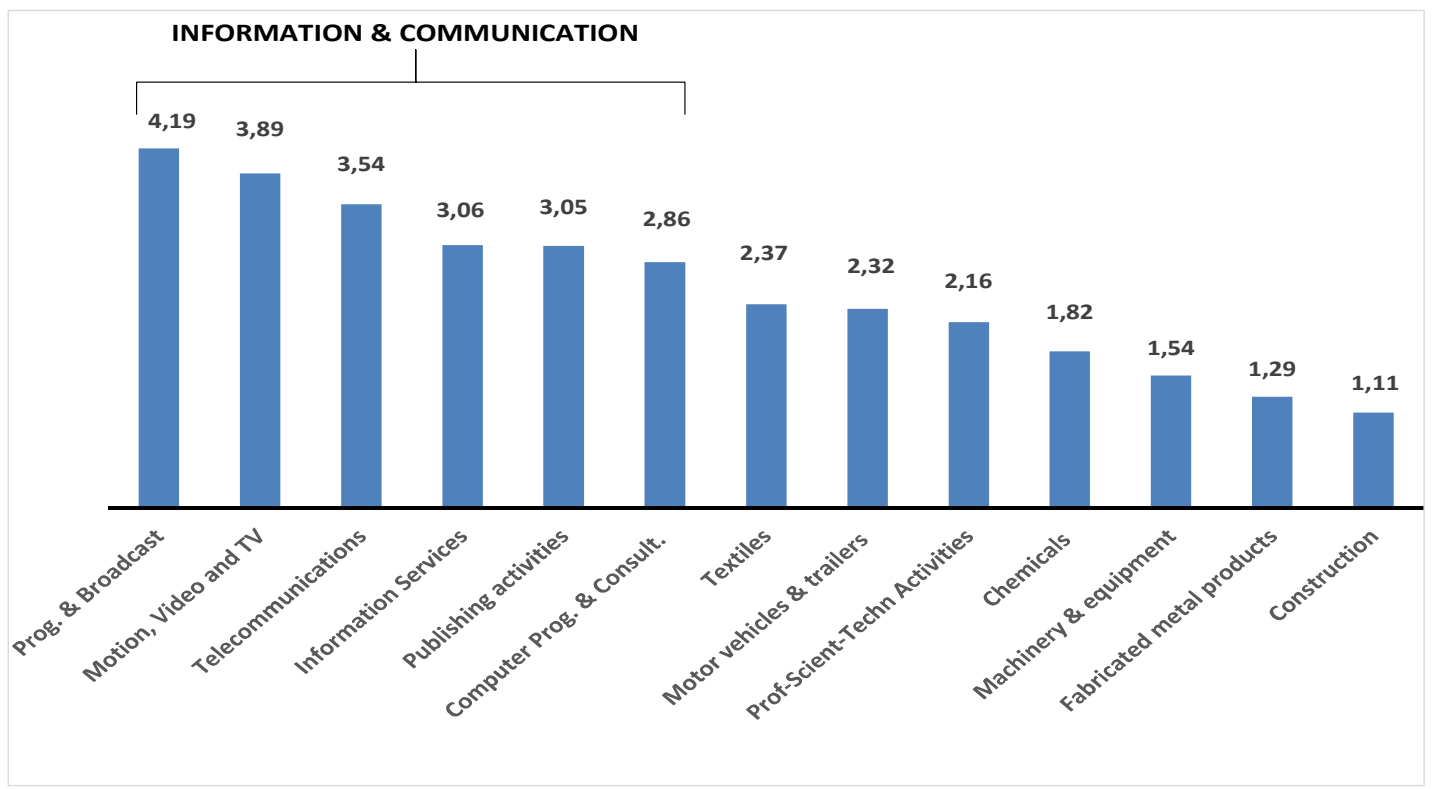

Source: Eurostat

These relationships are related to region and status of the member states. Countries in Northern Europe have higher levels of concentration than countries in the South, and in new member states as opposed to old ones, which have lagged in economic development.

Graph 5: Concentration (Ratio between Standard Deviation of Workers amongst Areas and Standard Deviation of Population), By country, Per cent, 2011.

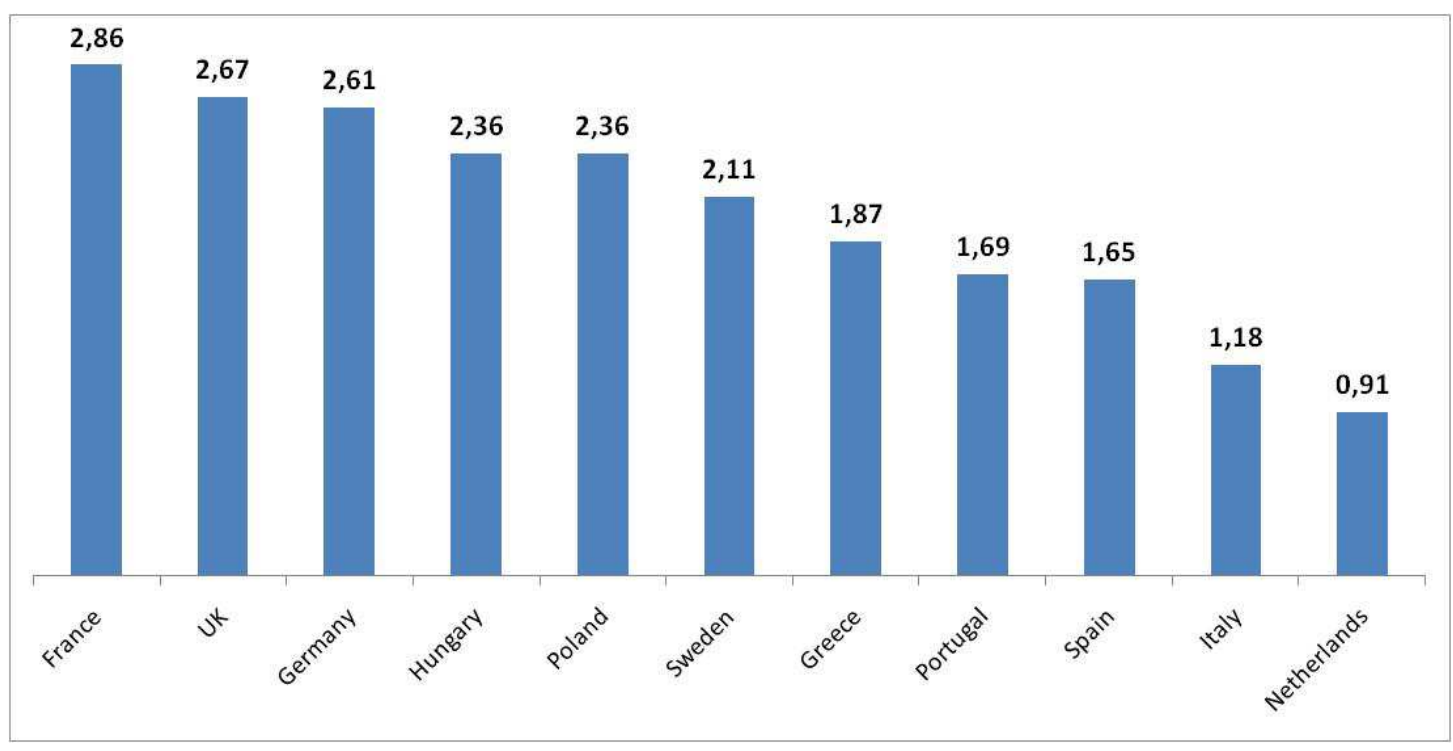

Source: Eurostat 
Again, it is useful to look at the relationship between concentration and accessibility as well as the use of ICTs. In this case we considered the second concentration index (the comparison between the percentage of the national work force employed in the five provinces - or regions - with the highest number of workers in a certain industry and the percentage of population in the five most populated regions) and correlated it with the use of Internet by business.

Graph 6: Correlation between Concentration (Percentage of the National Workforce Employed in the Five Provinces with the Highest Number of Workers) and Use of Internet from Business, 2013.

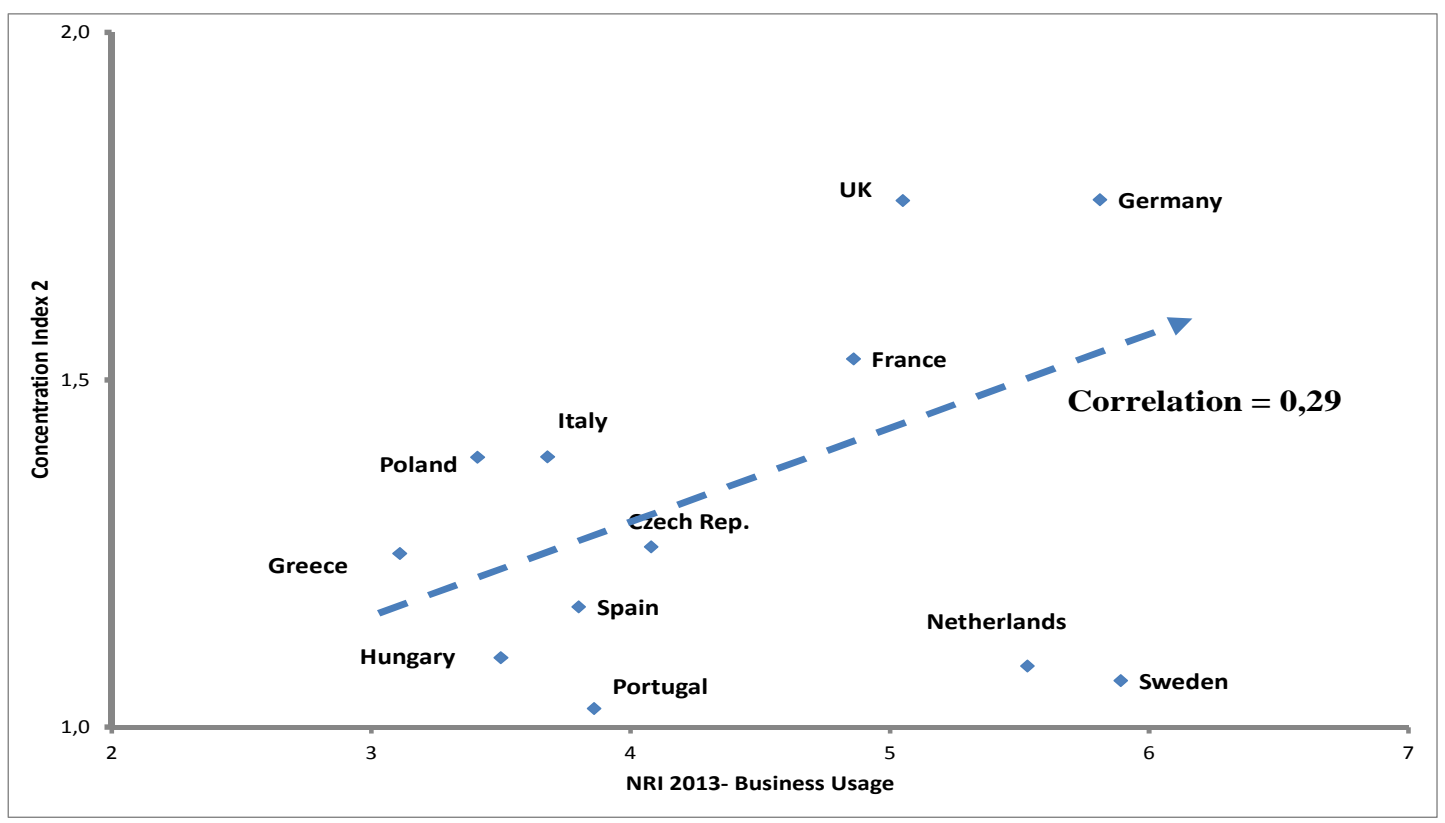

Source: Eurostat, WEF (network readiness index)

The correlation is 0,29 . The same relationship obtains $(0,29)$ when we correlate concentration and accessibility to ICT infrastructure or the diffusion of ICT as calculated by the World Bank.

Overall, the more a country shows a high propensity to use the Internet, the more its economic activities tend to be concentrated. And this relationship holds even when looking at concentration within each of the groups of countries: Southern Old Member states; Northern Old Member States; New Member States, and East Member States. The full set of correlations between the above mentioned concentration indexes and the four indicators of propensity to use ICT, is presented below. 
Table 1: Correlations amongst Concentration Indexes and Different Indicators of Propensity to Internet, Different Countries, 2012.

\begin{tabular}{|c|c|c|c|c|c|}
\hline & $\begin{array}{c}\text { INFRASTRUCTU } \\
\text { RE AND DIGITAL } \\
\text { CONTENT }\end{array}$ & $\begin{array}{l}\text { INDIVIDUA } \\
\text { L USAGE }\end{array}$ & $\begin{array}{l}\text { BUSINESS } \\
\text { USAGE }\end{array}$ & $\begin{array}{c}\text { GOVERNMENT } \\
\text { USAGE }\end{array}$ & ICT \\
\hline index 1 & 0,12 & $-0,07$ & $-0,02$ & $-0,20$ & $-0,04$ \\
\hline Index 2 & 0,29 & 0,19 & 0,29 & 0,13 & 0,29 \\
\hline Index 3 & 0,23 & 0,06 & 0,13 & $-0,01$ & 0,12 \\
\hline $\begin{array}{l}\text { evolution } \\
\text { index (1) }\end{array}$ & 0,35 & 0,10 & 0,29 & 0,17 & 0,15 \\
\hline
\end{tabular}

Source: Eurostat, World Bank (KEI), WEF (NRI)

Overall out of 20 correlations, 15 are positive and only one of these relationships is negative. The macro picture does not confirm Cairncross's prophecy: Internet is not 'killing' the distance and it may make it even stronger in some instances geography may matter more as ICTs enable access to information and networking. However, the associations we are mentioning are not straight forwardly linear. For example, some countries with a very high propensity towards digital technologies, such as Sweden and Netherlands, tend to be less concentrated. Also, as clear from the previous graph, the distribution of their economic activities tend to become even more distributed overtime.

\section{Discussion and Further Research}

Overall, the degree of stability overtime suggests that the traditional forces which were argued to be erased by the 'new economic geography' remain very significant. Distance remains an issue, and geography continues to matter, maybe even more in some cases. The continuing significance of traditional patterns of face-to-face communication and networking, such as informal communication or what some call 'soft' exchanges of knowledge, could be a factor reinforcing the importance of geography and patterns of clustering. This new 'geography of information' is arguably being reshaped at the margins around the space of flows, as well as the space of places, as the Internet is enabling patterns of communication that simply did not exist two decades ago. But the implications for the geography of industries is far more subtle and complex than implied by the logic behind a death of distance.

This paper marshals cross-national and longitudinal data to examine this thesis empirically, finding that the use and access to ICTs is more often positively related to greater concentration or clustering of industries within geographical areas. However, there are notable differences across industrial sectors and countries.

The results of the work support the general thesis that the use of digital media and related ICTs does not undermine the significance of distance or geography. In fact, geography might matter more as industries are less constrained in making locational decisions based on access to information, and more focused on putting people where they can benefit from face-to-face communication and networking. In 
line with this thesis, geography appears to be more important to the degree that businesses are more focused on the use of the Internet and related ICTs. Where the dependence is higher on information and knowledge industries, than on manufacturing plant which tend to manage physical assets, then distance is likely to matter more.

However, these tendencies are not strong, and much variation remains unexplained. Clearly, locational decisions are highly contingent on a large number of factors, only some of which have been identified in this analysis. For example, concentration of ICT industries has increased in those countries that have come from behind in the development of their digitalization infrastructures, and has decreased in countries with more mature digital infrastructures. This historical difference may explain why countries with highly developed digital infrastructures, such as Sweden and Netherlands, present relatively low and decreasing levels of concentration of their economic activities.

The absence of stronger relationships between digitization and locational concentration might also be explained on the basis of nonlinear relationships in the case of some variables. For example, some of the trends evidence a more U-shaped curve in the relationship, where industrial concentration can be higher at the extremes of 'Internet maturity'.

Overall, however, the results appear to counter Quah (1997), but reinforce and/or replicate the tendency for a geographical clustering or concentration around knowledge. However, the difficulty of clearly understanding what industries and firms tend to cluster together is the reason why many researchers (e.g. Anitra et al. 2008) have repeatedly insisted that it's time "to move away from the Silicon Valley model and to modestly start from a place-specific approach of 'Regional Realism'."

While the analysis of cross-national and longitudinal data presented in this paper adds credibility to models of clustering being supported by the diffusion of ICTs, it leaves much variation unexplained. It supports a shift of research away from overly simplistic models of the new economic geography, towards a more empirically refined understanding of how economic activities get redistributed as a consequence of firms and industries being enabled to digital infrastructures.

Overall, the paper confirms that the forces driving locational choices of firms and workers are changing. It is increasingly difficult to argue that economies of scale, transportation costs or distance from consumers is driving the location of economic activities. The role of intangible relationships appears more prominent than in previous models, with the Internet making information and network externalities even more important. Nevertheless, these forces are difficult to operationalize in ways that can demonstrate this role.

\subsection{Further Research}

There are major limitations of research in this area that need to be address by further research. First, there is a need to better operationalize many of the factors discussed here in order to explain why physical proximity appears to persist as a competitive advantage in some cases and not in others. This uncertainty contributes to tensions between different forms of understanding why and how industrial clustering of innovation is likely to succeed. For instance, as Ferrary and Granovetter (2009) stated: "The failure of several policy-makers around the world to reproduce the Silicon Valley cluster reveals the misunderstanding of the 
innovative dynamic in Silicon Valley... [constituted by a] complete and robust complex system of innovation supported by social networks of interdependent economic agents". Location on its own is unlikely to foster such social networks, but it can facilitate such networks in tandem with the right combination of other factors, such as digital media and networking.

The implications of the research may be particularly interesting for the EU and its regional development policies: What does the geography of information clusters in the current European landscape? What role is use of the Internet playing in redefining this geography? How can policymakers better understand and identify the role of centres and peripheries in a changing networked economy? What are the main sectors in which concentration is occurring and what patterns can be identified? Does the current economic context offer regional advantages that need to be addressed by public policy? What are the knowledge spill-overs, if any, that drive relocation in different geographies? How are these dynamics related to the scope, success and persistence of clusters? These and other questions should be explored in further research.

\section{Bibliography}

Allegrezza Serge, Dubrocard Anne (2012) Internet Econometrics, Palgrave MacMillan http://dx.doi.org/10.1057/9780230364226

Asheim Bjørn T, Boschma Ron, Cooke Philip (2011) Constructing Regional Advantage: Platform Policies Based on Related Variety and Differentiated Knowledge Bases, Regional Studies, Vol. 45, n. 7, November, pp. 893-904.

Barca Fabrizio (2009) An Agenda for Reformed Cohesion Policy, European Commission, Brussels..

Bauer Ramon; Koszegi Sabine.T.; Wolkerstorfer Martin, (2003) Measuring the Degree of Virtualization - an Empirical Analysis in two Austrian Industries, System Sciences, Proceedings of the 36th Annual Hawaii International Conference.

http://dx.doi.org/10.1109/HICSS.2003.1174797

Cairncross Frances (1997) The Death of Distance, Harvard Business School Press, Cambridge.

Camagni Roberto (1995) The Concept of Innovative Milieu and its Relevance for Public Policies in European Lagging Regions, Regional Science, Vol.74, (4), pp.317-40.

Casper Steven (2007) Creating Silicon Valley in Europe: Public Policy towards New Technology Industries, Oxford: University Press, Oxford.

Castells Manuel (2003) The Internet Galaxy: Reflections on the Internet, Business, and Society, Oxford University Press, New York.

http://dx.doi.org/9780199255771

Cisco (2010) Next Generation Clusters, Creating Innovation Hubs to Boost Economic Growth; Lange, Handler and Vila.

Coase Ronald H. (1937) The Nature of the Firm, Economica, Vol. 4, (4), November, pp. 386-405.

Cooke Philip (2007) To Construct Regional Advantage from Innovation Systems First Build Policy Platforms, European Planning Studies, Volume 15, Number 2, February 2007, pp. 179194(16)

Cummings Jonathon, Butler Brian, Kraut Robert (2002) The Quality of Online Social Relationships, Communications of the ACM - How the virtual inspires the real, Vol. 45, Issue 7, July, pp.103-108.

http://dx.doi.org/10.1145/514236.514242

Dutton William H. (1996) Information and Communication Technologies: Visions and Realities, Oxford University Press, New York. 
Feser Edward, Renski Henry, Goldstein Harvey (2008) Clusters and Economic Development Outcomes. An Analysis of the Link Between Clustering and Industry Growth, Economic Development Quarterly, November, Vol. 22, (4), pp. 324-344

http://dx.doi.org/10.1177/0891242408325419

Ferrary, Michel, Granovetter Mark (2009) The Role of Venture Capital Firms in Silicon Valley's Complex Innovation Network, Economy and Society, Vol. 38, (2), pp. 326-359.

http://dx.doi.org/10.1080/03085140902786827

Foray Dominique, Mowery David C., Nelson Richard R. (2012) The Need for a New Generation of Policy Instruments to Respond to the Grand Challenges, Research Policy, Vol. 41, (10), December, pp 1697-1792.

Foray Dominique, Van Ark Bart (2007) Smart Specialisation, Policy Brief No. 1, Expert Group Knowledge for Growth, European Commission, http://ec.europa.eu/invest-inresearch/pdf/download_en/policy_brief1.pdf

Freel Mark S. (2001) On Regional Systems of Innovation: Illustrations from the West Midlands, Environment and Planning C: Government and Policy, Vol. 20, pp. 633-654.

http://dx.doi.org/10.1068/c19m

Fritsch Michael (2004) Cooperation and the Efficiency of Regional R\&D Activities, Cambridge Journal of Economics, Vol. 28,(6), pp. 829-846.

http://dx.doi.org/10.1093/cje/beh039

Fritsch Michael, Slavtchev Viktor (2009) How does Industry Specialization Affect the Efficiency of Regional Innovation Systems? The Annals of Regional Science, Vol. 45, (1), August, pp. 87108.

http://dx.doi.org/10.1007/s00168-009-0292-9

Fujita Masahisa, Thisse Jacques Francois (2003) Economie des Villes et de la Localisation, De Boeck University Press, Louvain La Neuve.

Galliano Danielle, Orozco Louis (2013) New Technologies and Firm Organization: The Case of Electronic Traceability Systems in French Agribusiness, Industry \& Innovation, Vol. 20, (1), pp. 22-47.

http://dx.doi.org/10.1080/13662716.2013.761379

Gilbert, Brett Anitra, Patricia P. McDougall, and David B. Audretsch. (2008) Clusters, Knowledge Spillovers and New Venture Performance: An Empirical Examination, Journal of Business Venturing, Vol. 23, (4), pp. 405-422.

http://dx.doi.org/10.1016/j.jbusvent.2007.04.003

Giuliani Elisa (2005) Cluster Absorptive Capacity Why do Some Clusters Forge Ahead and Others Lag Behind? European Urban and Regional Studies, Vol. 12, (3), pp. 269-288. http://dx.doi.org/10.1177/0969776405056593

Goddard John, Richardson Ranald (1996) Why Geography Will Still Matter: What Jobs Go Where?, Dutton, W. H. (ed.), Information and Communication Technologies: Visions and Realities, Oxford University Press. Oxford.

Grillo Francesco, Landabaso Mikel (2011) Merits, Problems and Paradoxes of Regional Innovation Policies, Local Economy, November; Vol. 26, Issue 6-7, pp. 544-561.

http://dx.doi.org/10.1177/0269094211417161

Hospers Gert-Jan, Desrochers Pierre, Sautet Frédéric (2009) The Next Silicon Valley? On the Relationship between Geographical Clustering and Public Policy, International Entrepreneurship and Management Journal, Vol. 3 (5), pp. 285-299.

http://dx.doi.org/10.1007/s11365-008-0080-5

Hotelling Harold (1929) Stability in Competition, Economic Journal, Vol. 39, (153), pp. 41-57.

Jensen Morten B., Johnson Bjorn, Lorenz Edward, Lundvall Bend A. (2007) Forms of Knowledge and Modes of Innovation, Research Policy, Vol.36, (5); pp. 680-693.

http://dx.doi.org/10.1016/j.respol.2007.01.006 
Katz Michael L. (1986) An Analysis of Cooperative Research and Development, The RAND Journal of Economics, Vol. 17, No. 4, pp. 527-543.

Kraut Robert, Steinfield Charles, Chan Alice, Butler Brian, Hoag Anne (2006) Coordinaton and Virtualization: The Role of Electronic Networks and Personal Relationships, Journal of Computer-Mediated Communication, Vol. 3, (4), June.

http://dx.doi.org/10.1111/j.1083-6101.1998.tb00084.x

Krugman Paul, Venables Antony J. (1995) Globalization and the Inequality of Nations, The Quarterly Journal of Economics, Vol. 4, pp. 857-880.

http://dx.doi.org/10.2307/2946642

Kuemmerle Walter (1999) The Drivers of Foreign Direct Investment into Research and Development: an Empirical Investigation, Journal of International Business Studies, pp.1-24. http://dx.doi.org/10.1057/palgrave.jibs.8490058

Mazzanti Massimiliano, Montresor Sandro, Pini Paolo (2011) Outsourcing, Delocalization and Firm Organization: Transaction Costs versus Industrial Relations in a Local Production System of Emilia Romagna, Entrepreneurship \& Regional Development, Vol. 23, (7-8), pp. 419-447. http://dx.doi.org/10.1080/08985620903233986

Lewin Arie Y., Zhong Xing (2013) The Evolving Diaspora of Talent: A Perspective on Trends and Implications for Sourcing Science and Engineering Work. Journal of International Management, Vol. 19, (1), March, pp.6-13.

http://dx.doi.org/10.1016/j.intman.2012.10.001

Leydesdorff Loet (2000) The Triple Helix: an Evolutionary Model of Innovations, Research Policy, Vol. 29, (2), February, pp. 243-255.

http://dx.doi.org/10.1016/S0048-7333(99)00063-3

Lundvall Bend A. (1992) National Systems of Innovation,Pinter, London.

McCann Philip, Ortega-Argilés Raquel (2013) Transforming European Regional Policy: A Results-Driven Agenda and Smart Specialization, Oxford Review Economic Policy, Vol. 29, (2), pp. 405-431.

http://dx.doi.org/10.1093/oxrep/grt021

Nilles Jack M., Carlson Frederick R., Grey Paul, Hannaman Gerhard J. (1976) The Telecommunications-Transportation Tradeoff, John Wiley \& Sons, New York.

OECD (2009) Clusters, innovation and entrepreneurship, Potter and Miranda

Partridge Mark D., Rickman Dan S., (2003) Do We Know Economic Development When We See It?, The Review of Regional Studies, Vol. 33, (1), pp. 17-39.

Passiante Giustina Secundo (2002) From Geographical Innovation Clusters towards Virtual Innovation Clusters: The Innovation Virtual System, Paper presented at 42th ERSA Congress From Industry to Advanced Services - Perspectives of European Metropolitan Regions University of Dortmund (Germany), 27-31 August 2002

Porter Michael E. (2000) Location, Competition, and Economic Development: Local Clusters in a Global Economy. Economic Development Quarterly, Vol. 14, (1), pp. 15-34. http://dx.doi.org/10.1177/089124240001400105

Porter Michael E. (1990) The Competitive Advantage of Nations, The Free Press, New York. http://dx.doi.org/10.1002/cir.3880010112

Quah Danny T. (1997) Internet Cluster Emergence, European Economic Review, Vol. 44, (4-6), May, pp. 1032-1044.

http://dx.doi.org/10.1016/S0014-2921(99)00055-0

Sher Peter J., Yang Phil Y. (2005) The Effects of Innovative Capabilities and R\&D Clustering on Firm Performance: The Evidence of Taiwan's Semiconductor Industry, Technovation, Vol. 25, (1), pp. 33-43.

http://dx.doi.org/10.1016/S0166-4972(03)00068-3 
Sturgeon Timothy, van Biesebroeck Johannes, Gereffi Gary. (2008) Value Chains, Networks and Clusters: Reframing the Global Automotive Industry. Journal of Economic Geography, 8(3), 297-321.

http://dx.doi.org/10.1093/jeg/lbn007

Rifkin Jeremy (2014) The Zero Marginal Cost Society: The Internet of Things, the Collaborative Commons, and the Eclipse of Capitalism. Palgrave MacMillan.

Von Thunen Johann Heinrich (1826) The Isolated State, English edn, Pergamon Press, London.

Vicente Jérôme. (2003) Ambivalences of 'Silicon Label': Network Externalities vs. Information Externalities in Location Dynamics, RSA Conference, March, Pisa.

West Darrell M (2004) E-Government and the Transformation of Service Delivery and Citizen Attitudes, Public Administration Review http://dx.doi.org/10.1111/j.1540-6210.2004.00343.x

Wilson Ernest J. (2004) The Information Revolution and Developing Countries, MIT Press, Cambridge.

Zhang Yan, Haiyang Li (2010) Innovation Search of New Ventures in a Technology Cluster: the Role of Ties with Service Intermediaries, Strategic Management Journal, Vol. 31, (1), pp. 88109.

http://dx.doi.org/10.1002/smj.806 


\section{Annex 1 - The Data}

Concentration, analysed sectors, By provinces (NUTS 3), Standard deviation (number of employees), Percentage of employees in top 5 Provinces (1)

\begin{tabular}{|c|c|c|c|c|c|c|c|}
\hline \multirow{2}{*}{ COUNTRIES } & \multirow{2}{*}{ SECTORS } & Change \% & Concentration & $\%$ employees & Concentration & $\%$ employees & Concentration \\
\hline & & $(2011-2008)$ & index (1) & top 5 provinces & index (2) & top 1 province & index (3) \\
\hline \multirow{13}{*}{ UK } & Manufacture of textiles & $4,81 \%$ & 2,54 & $50,02 \%$ & 1,94 & $19,43 \%$ & 2,50 \\
\hline & Manufacture of chemicals and chemical products & $24,27 \%$ & 1,34 & $31,50 \%$ & 1,22 & $8,25 \%$ & 1,06 \\
\hline & Manufacture of fabricated metal products, except & $-27,25 \%$ & 1,26 & $28,82 \%$ & 1,12 & $10,39 \%$ & 1,33 \\
\hline & Manufacture of machinery and equipment n.e.c. & $10,11 \%$ & 1,32 & $30,41 \%$ & 1,18 & $7,17 \%$ & 0,92 \\
\hline & Manufacture of motor vehicles, trailers and semi- & $3,94 \%$ & 2,09 & $39,69 \%$ & 1,54 & $15,82 \%$ & 2,03 \\
\hline & Publishing activities & $15,28 \%$ & 3,93 & $55,04 \%$ & 2,14 & $34,17 \%$ & 4,39 \\
\hline & Motion picture, video and television program & $-1,79 \%$ & 5,77 & $69,20 \%$ & 2,69 & $50,02 \%$ & 6,42 \\
\hline & Programming and broadcasting activities & $-15,18 \%$ & 5,38 & $77,81 \%$ & 3,02 & $35,38 \%$ & 4,54 \\
\hline & Telecommunications & $-13,73 \%$ & 1,84 & $36,94 \%$ & 1,44 & $13,29 \%$ & 1,71 \\
\hline & Computer programming and consultancy & $10,71 \%$ & 2,54 & $51,06 \%$ & 1,98 & $18,14 \%$ & 2,33 \\
\hline & Information service activities & $4,86 \%$ & 3,25 & $52,35 \%$ & 2,03 & $26,64 \%$ & 3,42 \\
\hline & Construction & $-3,98 \%$ & 0,82 & $22,7 \%$ & 0,88 & $8,27 \%$ & 1,06 \\
\hline & Professional, scientific and technical activities & $6,45 \%$ & 2,43 & $42,6 \%$ & 1,66 & $13,99 \%$ & 1,80 \\
\hline \multirow{13}{*}{ GERMANY } & Manufacture of textiles & $7,19 \%$ & 2,08 & $39,81 \%$ & 1,49 & $12,4 \%$ & 1,97 \\
\hline & Manufacture of chemicals and chemical product & $-2,88 \%$ & 2,55 & $51,34 \%$ & 1,92 & $12,4 \%$ & 1,97 \\
\hline & Manufacture of fabricated metal products, except & $-24,42 \%$ & 1,65 & $36,11 \%$ & 1,35 & $11,5 \%$ & 1,82 \\
\hline & Manufacture of machinery and equipment n.e.c. & $-4,56 \%$ & 1,73 & $35,01 \%$ & 1,31 & $13,2 \%$ & 2,09 \\
\hline & Manufacture of motor vehicles, trailers and semi- & $44,42 \%$ & 2,57 & $41,86 \%$ & 1,57 & $17,2 \%$ & 2,73 \\
\hline & Publishing activities & $13,22 \%$ & 1,81 & $38,99 \%$ & 1,46 & $10,47 \%$ & 1,66 \\
\hline & Motion picture, video and television program & $13,38 \%$ & 2,96 & $58,59 \%$ & 2,20 & $15,29 \%$ & 2,43 \\
\hline & Programming and broadcasting activities & $0,13 \%$ & 3,81 & $66,88 \%$ & 2,51 & $17,79 \%$ & 2,82 \\
\hline & Telecommunications & $-9,38 \%$ & 6,74 & $83,88 \%$ & 3,14 & $46,04 \%$ & 7,31 \\
\hline & Computer programming and consultancy & $12,26 \%$ & 2,44 & $49,22 \%$ & 1,84 & $14,25 \%$ & 2,26 \\
\hline & Information service activities & $-21,94 \%$ & 2,17 & $45,00 \%$ & 1,69 & $11,04 \%$ & 1,75 \\
\hline & Construction & $-3,98 \%$ & 0,84 & $23,6 \%$ & 0,88 & $5,33 \%$ & 0,85 \\
\hline & Professional, scientific and technical activities & $6,45 \%$ & 2,49 & $40,1 \%$ & 1,50 & $9,65 \%$ & 1,53 \\
\hline \multirow{13}{*}{ FRANCE } & Manufacture of textiles & $18,65 \%$ & 1,55 & $64,30 \%$ & 1,36 & $23,86 \%$ & 1,31 \\
\hline & Manufacture of chemicals and chemical products & & 2,48 & $75,25 \%$ & 1,59 & $46,86 \%$ & 2,57 \\
\hline & Manufacture of fabricated metal products, except & $12,32 \%$ & 1,08 & $50,98 \%$ & 1,08 & $16,19 \%$ & 0,89 \\
\hline & Manufacture of machinery and equipment n.e.c. & $39,05 \%$ & 1,43 & $59,74 \%$ & 1,26 & $21,28 \%$ & 1,17 \\
\hline & Manufacture of motor vehicles, trailers and semi- & & 3,57 & $85,86 \%$ & 1,82 & $63,41 \%$ & 3,48 \\
\hline & Publishing activities & $-7,21 \%$ & 3,24 & $77,36 \%$ & 1,64 & $49,28 \%$ & 2,70 \\
\hline & Motion picture, video and television program & $-14,75 \%$ & 4,06 & $84,65 \%$ & 1,79 & $66,25 \%$ & 3,63 \\
\hline & Programming and broadcasting activities & $6,74 \%$ & & & & $64,11 \%$ & 3,52 \\
\hline & Telecommunications & $2,30 \%$ & 6,22 & $96,01 \%$ & 2,03 & $64,82 \%$ & 3,55 \\
\hline & Computer programming and consultancy & $-6,80 \%$ & 3,60 & $87,81 \%$ & 1,86 & $43,51 \%$ & 2,39 \\
\hline & Information service activities & $-6,15 \%$ & 3,14 & $66,33 \%$ & 1,40 & $44,88 \%$ & 2,46 \\
\hline & Construction & $1,44 \%$ & 1,04 & $49,10 \%$ & 1,04 & $18,31 \%$ & 1,00 \\
\hline & Professional, scientific and technical activities & $-1,10 \%$ & 2,32 & $69,86 \%$ & 1,48 & $38,04 \%$ & 2,09 \\
\hline & Manufacture of textiles & $-2,37 \%$ & 0,34 & $84,64 \%$ & 1,63 & $39,16 \%$ & 2,38 \\
\hline & Manufacture of chemicals and chemical product & $-11,94 \%$ & 0,35 & $76,19 \%$ & 1,47 & $41,08 \%$ & 2,50 \\
\hline & Manufacture of fabricated metal products, except & $-12,87 \%$ & 0,25 & $68,41 \%$ & 1,32 & $28,69 \%$ & 1,75 \\
\hline & Manufacture of machinery and equipment n.e.c. & $0,24 \%$ & 0,30 & $82,46 \%$ & 1,59 & $28,80 \%$ & 1,75 \\
\hline & Manufacture of motor vehicles, trailers and semi- & $-27,60 \%$ & 0,28 & $70,69 \%$ & 1,36 & $31,08 \%$ & 1,89 \\
\hline & Publishing activities & $-1,11 \%$ & 1,96 & $75,91 \%$ & 1,46 & $36,26 \%$ & 2,21 \\
\hline ITALY & Motion picture, video and television program & $0,38 \%$ & 2,53 & $81,17 \%$ & 1,56 & $25,44 \%$ & 1,55 \\
\hline & Programming and broadcasting activities & $-0,32 \%$ & 2,37 & $80,00 \%$ & 1,54 & $45,85 \%$ & 2,79 \\
\hline & Telecommunications & $6,02 \%$ & 1,68 & $69,32 \%$ & 1,33 & $41,01 \%$ & 2,50 \\
\hline & Computer programming and consultancy & $-3,18 \%$ & 1,73 & $75,25 \%$ & 1,45 & $27,80 \%$ & 1,69 \\
\hline & Information service activities & $0,60 \%$ & 1,32 & $61,71 \%$ & 1,19 & $28,69 \%$ & 1,75 \\
\hline & Construction & $0,35 \%$ & 1,05 & $53,12 \%$ & 1,02 & $18,77 \%$ & 1,14 \\
\hline & Professional, scientific and technical activities & $0,13 \%$ & 1,27 & $59,58 \%$ & 1,15 & $23,20 \%$ & 1,41 \\
\hline & Manufacture of textiles & $-28,09 \%$ & 2,12 & $83,08 \%$ & 1,29 & $40,26 \%$ & 2,24 \\
\hline & Manufacture of chemicals and chemical products & $-16,47 \%$ & 1,80 & $75,20 \%$ & 1,17 & $39,46 \%$ & 2,20 \\
\hline & Manufacture of fabricated metal products, except & $-18,76 \%$ & 1,03 & $63,20 \%$ & 0,98 & $20,68 \%$ & 1,15 \\
\hline & Manufacture of machinery and equipment n.e.c. & $-16,99 \%$ & 1,30 & $71,87 \%$ & 1,12 & $23,58 \%$ & 1,31 \\
\hline & Manufacture of motor vehicles, trailers and semi- & $-24,57 \%$ & 1,30 & $66,17 \%$ & 1,03 & $26,02 \%$ & 1,45 \\
\hline & Publishing activities & $7,59 \%$ & 1,78 & $78,92 \%$ & 1,23 & $38,19 \%$ & 2,13 \\
\hline SPAIN & Motion picture, video and television program & $5,01 \%$ & 1,85 & $81,89 \%$ & 1,27 & $41,42 \%$ & 2,31 \\
\hline & Programming and broadcasting activities & $4,47 \%$ & 1,56 & $76,51 \%$ & 1,19 & $35,30 \%$ & 1,97 \\
\hline & Telecommunications & $5,42 \%$ & 1,78 & $78,69 \%$ & 1,22 & $41,59 \%$ & 2,32 \\
\hline & Computer programming and consultancy & $-7,36 \%$ & 2,23 & $84,97 \%$ & 1,32 & $49,09 \%$ & 2,74 \\
\hline & Information service activities & $1,66 \%$ & 2,15 & $84,57 \%$ & 1,31 & $46,75 \%$ & 2,61 \\
\hline & Construction & $-2,77 \%$ & 0,95 & $62,53 \%$ & 0,97 & $14,62 \%$ & 0,82 \\
\hline & Professional, scientific and technical activities & $1,26 \%$ & 1,32 & $73,95 \%$ & 1,15 & $25,57 \%$ & 1,43 \\
\hline & Manufacture of textiles & $-12,90 \%$ & 2,08 & $73,42 \%$ & 1,50 & $23,80 \%$ & 1,73 \\
\hline & Manufacture of chemicals and chemical products & $-26,18 \%$ & 1,59 & $57,50 \%$ & 1,18 & $21,30 \%$ & 1,55 \\
\hline & Manufacture of fabricated metal products, except & $-11,07 \%$ & 1,17 & $52,89 \%$ & 1,08 & $16,64 \%$ & 1,21 \\
\hline & Manufacture of machinery and equipment n.e.c. & $-15,85 \%$ & 1,17 & $54,30 \%$ & 1,11 & $15,03 \%$ & 1,09 \\
\hline & Manufacture of motor vehicles, trailers and semi- & $19,98 \%$ & 2,43 & $72,61 \%$ & 1,49 & $31,74 \%$ & 2,31 \\
\hline & Publishing activities & $-7,14 \%$ & 2,88 & $74,42 \%$ & 1,52 & $39,49 \%$ & 2,87 \\
\hline POLAND & Motion picture, video and television program & $-9,00 \%$ & 3,52 & $77,07 \%$ & 1,58 & $48,20 \%$ & 3,50 \\
\hline & Programming and broadcasting activities & $13,23 \%$ & 3,88 & $74,82 \%$ & 1,53 & $53,41 \%$ & 3,88 \\
\hline & Telecommunications & $10,70 \%$ & 3,62 & $77,07 \%$ & 1,58 & $49,68 \%$ & 3,61 \\
\hline & Computer programming and consultancy & $-2,48 \%$ & 2,31 & $71,06 \%$ & 1,46 & $30,95 \%$ & 2,25 \\
\hline & Information service activities & $-23,52 \%$ & 2,36 & $72,91 \%$ & 1,49 & $31,16 \%$ & 2,26 \\
\hline & Construction & $-1,26 \%$ & 1,25 & $56,70 \%$ & 1,16 & $15,72 \%$ & 1,14 \\
\hline & Professional, scientific and technical activities & $2,14 \%$ & 2,00 & $66,84 \%$ & 1,37 & $27,42 \%$ & 1,99 \\
\hline
\end{tabular}


Concentration, analysed sectors, By provinces (NUTS 3), Standard deviation (number of employees), Percentage of employees in top 5 Provinces - continuing

\begin{tabular}{|c|c|c|c|c|c|c|c|}
\hline \multirow{2}{*}{ COUNTRIES } & \multirow{2}{*}{ SECTORS } & Change \% & Concentration & $\%$ employees & Concentration & $\%$ employees & Concentration \\
\hline & & $(2011-2008)$ & index (1) & top 5 provinces & index (2) & top 1 province & index (3) \\
\hline \multirow{13}{*}{ NETHERLANDS } & Manufacture of textiles & $2,10 \%$ & 0,51 & $83,43 \%$ & 1,16 & $26,32 \%$ & 1,24 \\
\hline & Manufacture of chemicals and chemical product $\$$ & $-11,64 \%$ & 0,35 & $70,94 \%$ & 0,99 & $20,69 \%$ & 0,97 \\
\hline & Manufacture of fabricated metal products, except & $-5,57 \%$ & 0,32 & $69,17 \%$ & 0,97 & $21,09 \%$ & 0,99 \\
\hline & Manufacture of machinery and equipment n.e.c. & $9,90 \%$ & 0,42 & $75,83 \%$ & 1,06 & $28,01 \%$ & 1,32 \\
\hline & Manufacture of motor vehicles, trailers and semi- & $7,84 \%$ & 0,61 & $82,03 \%$ & 1,15 & $41,10 \%$ & 1,94 \\
\hline & Publishing activities & $-3,67 \%$ & 1,60 & $80,50 \%$ & 1,12 & $36,30 \%$ & 1,71 \\
\hline & Motion picture, video and television program & & & n.a. & & & - \\
\hline & Programming and broadcasting activities & & & n.a. & & & - \\
\hline & Telecommunications & $-6,19 \%$ & 1,51 & $78,06 \%$ & 1,09 & $28,78 \%$ & 1,35 \\
\hline & Computer programming and consultancy & $-1,02 \%$ & 1,34 & $85,03 \%$ & 1,19 & $21,74 \%$ & 1,02 \\
\hline & Information service activities & $5,31 \%$ & 1,42 & $77,74 \%$ & 1,09 & $29,39 \%$ & 1,38 \\
\hline & Construction & $-0,67 \%$ & 1,07 & $73,66 \%$ & 1,03 & $22,65 \%$ & 1,07 \\
\hline & Professional, scientific and technical activities & $-0,14 \%$ & 1,26 & $81,16 \%$ & 1,13 & $22,82 \%$ & 1,07 \\
\hline \multirow{13}{*}{ HUNGARY } & Manufacture of textiles & $-41,17 \%$ & 0,61 & $79,11 \%$ & 0,98 & $22,78 \%$ & 0,76 \\
\hline & Manufacture of chemicals and chemical products & $-15,73 \%$ & 1,75 & $91,86 \%$ & 1,14 & $35,58 \%$ & 1,19 \\
\hline & Manufacture of fabricated metal products, except & $-14,20 \%$ & 0,71 & $77,90 \%$ & 0,97 & $25,29 \%$ & 0,85 \\
\hline & Manufacture of machinery and equipment n.e.c. & $0,67 \%$ & 0,86 & $85,76 \%$ & 1,06 & $23,11 \%$ & 0,78 \\
\hline & Manufacture of motor vehicles, trailers and semi- & $-3,45 \%$ & 1,80 & $93,60 \%$ & 1,16 & $32,96 \%$ & 1,11 \\
\hline & \begin{tabular}{|l} 
Publishing activities \\
\end{tabular} & $-4,07 \%$ & 3,40 & $94,54 \%$ & 1,17 & $68,93 \%$ & 2,31 \\
\hline & Motion picture, video and television program & $1,22 \%$ & 4,07 & $94,74 \%$ & 1,17 & $79,90 \%$ & 2,68 \\
\hline & \begin{tabular}{|l|} 
Programming and broadcasting activities \\
\end{tabular} & $-16,84 \%$ & 3,24 & $91,58 \%$ & 1,13 & $66,44 \%$ & 2,23 \\
\hline & Telecommunications & $-2,47 \%$ & 3,12 & $89,70 \%$ & 1,11 & $64,65 \%$ & 2,17 \\
\hline & Computer programming and consultancy & $1,84 \%$ & 3,76 & $93,49 \%$ & 1,16 & $74,88 \%$ & 2,51 \\
\hline & Information service activities & $0,95 \%$ & 3,57 & $92,31 \%$ & 1,14 & $71,72 \%$ & 2,41 \\
\hline & Construction & $-5,67 \%$ & 1,38 & $81,29 \%$ & 1,01 & $36,29 \%$ & 1,22 \\
\hline & Professional, scientific and technical activities & $-0,41 \%$ & 2,75 & $88,35 \%$ & 1,09 & $58,64 \%$ & 1,97 \\
\hline \multirow{13}{*}{ SWEDEN } & Manufacture of textiles & $-8,29 \%$ & 2,26 & $91,45 \%$ & 1,11 & $49,02 \%$ & 2,20 \\
\hline & Manufacture of chemicals and chemical product $\$$ & $-14,71 \%$ & 1,40 & $89,47 \%$ & 1,09 & $23,54 \%$ & 1,06 \\
\hline & Manufacture of fabricated metal products, except & $14,21 \%$ & 1,12 & $85,01 \%$ & 1,03 & $24,72 \%$ & 1,11 \\
\hline & Manufacture of machinery and equipment n.e.c. & $-3,32 \%$ & 1,08 & $84,89 \%$ & 1,03 & $22,81 \%$ & 1,02 \\
\hline & Manufacture of motor vehicles, trailers and semi- & $15,05 \%$ & 2,75 & $76,23 \%$ & 0,93 & $50,66 \%$ & 2,28 \\
\hline & Publishing activities & $-2,70 \%$ & 1,98 & $90,16 \%$ & 1,10 & $44,15 \%$ & 1,98 \\
\hline & Motion picture, video and television program & $2,11 \%$ & 3,51 & $95,64 \%$ & 1,16 & $71,62 \%$ & 3,22 \\
\hline & Programming and broadcasting activities & $4,33 \%$ & 2,64 & $88,08 \%$ & 1,07 & $56,92 \%$ & 2,56 \\
\hline & Telecommunications & $7,29 \%$ & 2,13 & $84,42 \%$ & 1,03 & $48,02 \%$ & 2,16 \\
\hline & Computer programming and consultancy & $1,06 \%$ & 2,27 & $90,81 \%$ & 1,10 & $48,87 \%$ & 2,20 \\
\hline & Information service activities & $0,23 \%$ & 3,12 & $93,05 \%$ & 1,13 & $65,21 \%$ & 2,93 \\
\hline & Construction & $1,28 \%$ & 1,10 & $82,94 \%$ & 1,01 & $24,36 \%$ & 1,09 \\
\hline & Professional, scientific and technical activities & $0,79 \%$ & 1,81 & $89,07 \%$ & 1,08 & $39,68 \%$ & 1,78 \\
\hline & Manufacture of textiles & $32,26 \%$ & 1,32 & $89,99 \%$ & 1,26 & $35,80 \%$ & 1,01 \\
\hline & Manufacture of chemicals and chemical products & & 1,68 & $92,61 \%$ & 1,30 & $56,68 \%$ & 1,60 \\
\hline & Manufacture of fabricated metal products, except & $15,32 \%$ & 1,23 & $79,23 \%$ & 1,11 & $42,32 \%$ & 1,19 \\
\hline & Manufacture of machinery and equipment n.e.c. & $13,55 \%$ & 1,54 & $93,12 \%$ & 1,31 & $38,06 \%$ & 1,07 \\
\hline & Manufacture of motor vehicles, trailers and semi- & $-15,41 \%$ & 1,39 & $88,24 \%$ & 1,24 & $38,98 \%$ & 1,10 \\
\hline & Publishing activities & $-4,34 \%$ & 2,29 & $93,77 \%$ & 1,32 & $77,36 \%$ & 2,18 \\
\hline GREECE & Motion picture, video and television program & $-2,50 \%$ & 2,42 & $93,68 \%$ & 1,32 & $81,73 \%$ & 2,31 \\
\hline & Programming and broadcasting activities & $-8,42 \%$ & 2,00 & $90,60 \%$ & 1,27 & $67,68 \%$ & 1,91 \\
\hline & Telecommunications & $3,98 \%$ & 2,78 & $91,65 \%$ & 1,29 & $75,09 \%$ & 2,12 \\
\hline & Computer programming and consultancy & $-14,58 \%$ & 2,31 & $92,25 \%$ & 1,30 & $72,07 \%$ & 2,03 \\
\hline & Information service activities & & 2,17 & $92,14 \%$ & 1,29 & $73,85 \%$ & 2,08 \\
\hline & Construction & & 1,28 & $75,25 \%$ & 1,06 & $45,82 \%$ & 1,29 \\
\hline & Professional, scientific and technical activities & $-6,03 \%$ & 1,74 & $84,54 \%$ & 1,19 & $60,10 \%$ & 1,70 \\
\hline & Manufacture of textiles & $33,23 \%$ & 2,92 & $99,14 \%$ & 1,04 & $82,81 \%$ & 2,37 \\
\hline & Manufacture of chemicals and chemical product & $-57,27 \%$ & 0,68 & $99,11 \%$ & 1,04 & $32,48 \%$ & 0,93 \\
\hline & Manufacture of fabricated metal products, except & $2,46 \%$ & 1,28 & $96,70 \%$ & 1,02 & $41,33 \%$ & 1,18 \\
\hline & Manufacture of machinery and equipment n.e.c. & $17,77 \%$ & 1,55 & $98,87 \%$ & 1,04 & $50,46 \%$ & 1,44 \\
\hline & Manufacture of motor vehicles, trailers and semi- & $36,17 \%$ & 1,26 & $99,83 \%$ & 1,05 & $46,22 \%$ & 1,32 \\
\hline & Publishing activities & $8,58 \%$ & 1,77 & $97,63 \%$ & 1,03 & $55,23 \%$ & 1,58 \\
\hline PORTUGAL & Motion picture, video and television program & $5,46 \%$ & 1,78 & $97,42 \%$ & 1,02 & $66,52 \%$ & 1,90 \\
\hline & Programming and broadcasting activities & $33,51 \%$ & 2,24 & $97,69 \%$ & 1,03 & $68,76 \%$ & 1,97 \\
\hline & Telecommunications & $27,15 \%$ & 2,01 & $95,90 \%$ & 1,01 & $62,45 \%$ & 1,79 \\
\hline & Computer programming and consultancy & $-2,32 \%$ & 1,82 & $98,60 \%$ & 1,04 & $67,21 \%$ & 1,92 \\
\hline & Information service activities & $5,05 \%$ & 1,94 & $97,78 \%$ & 1,03 & $61,84 \%$ & 1,77 \\
\hline & Construction & $5,88 \%$ & 0,99 & $94,61 \%$ & 0,99 & $37,68 \%$ & 1,08 \\
\hline & Professional, scientific and technical activities & $-0,95 \%$ & 1,26 & $97,11 \%$ & 1,02 & $44,28 \%$ & 1,27 \\
\hline & Manufacture of textiles & $7,06 \%$ & 7,27 & $87,52 \%$ & 1,32 & $41,62 \%$ & 2,61 \\
\hline & Manufacture of chemicals and chemical products & $17,60 \%$ & 3,35 & $78,46 \%$ & 1,19 & $21,89 \%$ & 1,37 \\
\hline & Manufacture of fabricated metal products, except & $15,53 \%$ & 2,45 & $75,39 \%$ & 1,14 & $18,48 \%$ & 1,16 \\
\hline & Manufacture of machinery and equipment n.e.c. & $20,68 \%$ & 3,40 & $79,36 \%$ & 1,20 & $23,12 \%$ & 1,45 \\
\hline & Manufacture of motor vehicles, trailers and semi- & $-8,23 \%$ & 5,09 & $85,90 \%$ & 1,30 & $28,66 \%$ & 1,79 \\
\hline & Publishing activities & $-10,38 \%$ & 9,96 & $85,81 \%$ & 1,30 & $55,21 \%$ & 3,46 \\
\hline CZECH REP. & Motion picture, video and television program & $-9,12 \%$ & 10,33 & $86,71 \%$ & 1,31 & $57,01 \%$ & 3,57 \\
\hline & Programming and broadcasting activities & $-13,40 \%$ & 14,96 & $95,26 \%$ & 1,44 & $77,13 \%$ & 4,83 \\
\hline & Telecommunications & $4,34 \%$ & 9,02 & $86,69 \%$ & 1,31 & $51,00 \%$ & 3,19 \\
\hline & Computer programming and consultancy & $-3,42 \%$ & 8,00 & $86,73 \%$ & 1,31 & $44,74 \%$ & 2,80 \\
\hline & Information service activities & $6,00 \%$ & 10,08 & $88,26 \%$ & 1,33 & $55,03 \%$ & 3,45 \\
\hline & Construction & $3,86 \%$ & 1,49 & $69,33 \%$ & 1,05 & $17,24 \%$ & 1,08 \\
\hline & Professional, scientific and technical activities & $-1,22 \%$ & 5,31 & $77,31 \%$ & 1,17 & $35,27 \%$ & 2,21 \\
\hline
\end{tabular}




\section{Notes}

${ }^{1}$ Some argue that such an agglomeration takes place even if the endowments of the regions are equivalent (i.e. their "comparative" positions are equal). In fact, the agglomerated industries tend to enjoy increasing returns to scale even if the geographical contexts are equivalent at the start (Allen et al., 1998, again Krugman, 1999, Porter, 2000). Competitive pressures tend to increase the average productivity, and proximity to suppliers tends to reduce prices of the initial production factors. So even if it is just by chance, the movement of a firm from one region to another is expected to produce - in a low trade cost model - a self-accumulation process that can significantly concentrate the industry base

${ }^{2}$ Although the first systems of innovation to be conceptualized were the national ones by Lundvall (Lundvall, 1992)and Nelson (Nelson, 1993)

${ }^{3}$ Putman (Putman et al., 1993) would have called it social capital, although here we are talking about a more committing and pervasive form of it.

${ }^{4}$ The idea that world cities configure aggregation-sites for knowledge-intensive businesses and for populations is further analysed by Brondoni and Cappellin (2011).

${ }^{5}$ Eurostat is the statistical office of the European Union and supply statistics at European level that enable comparisons between countries and regions

http://epp.eurostat.ec.europa.eu/portal/page/portal/about_eurostat/introduction

${ }^{6}$ Eurostat is the statistical office of the European Union and supply statistics at European level that enable comparisons between countries and regions.

http://epp.eurostat.ec.europa.eu/portal/page/portal/about_eurostat/introduction

${ }^{7}$ Given the spatial articulation of EUROSTAT database, we considered "regions" (the ones which are classified as NUTS 2 areas by EUROSTAT) in France, Italy and Spain, and "provinces" (the NUTS 3) in Germany and UK. 